\title{
Hicks' thread (out of the equilibrium labyrinth)
}

\section{Abstract}

The work of John Hicks is an unending source of inspiration for many economists and an unsolved dilemma for historians of economic thought. These pages highlight the fact that Hicks' peculiar perspective on the economic agent constitutes the substructure underlying his research path, and the common premise to his theories of markets, liquidity, capital, and risk. Hicks' theory of the agent was intended to address the factual role of non-measurable risk (i.e., learning-management), and was primarily concerned with the price- and wealth-effects that the transaction costs (costs of learning and moving) entail for learning-induced behaviours.

JEL codes: B31, D90, E41.

Key words: Micro-Foundations, Non-Measurable Risk, Transaction Costs, Liquidity Constraints, Fixprice.

It is the new things that humanity has discovered which makes its history exciting; and the new things that may be found in the future, before humanity blows itself up, or settles down to some ghastly 'equilibrium', make a future worth praying for, and worth working for. (Hicks 1976B [1982], p. 300)

\section{John and the Johns}

John Richard Hicks (1904-1989), 'one of the last great generalists in a discipline that is more and more balkanized into pointed specializations' (Dostaler, 2001, p. 22), is still a source of inspiration for economists of all schools and an unsolved dilemma for historians of economic thought. In 1972 he shared a Nobel Prize for his contributions to general equilibrium theory and welfare economics; yet he greeted this honour 'with mixed feelings' (Hicks, 1977, p. v). The inner chagrin he repressed on that solemn occasion broke free some years later, in a joking-provocative tone, after the umpteenth 'neo-classicist' interpretation of his oeuvre: 
Clearly I need to change my name. Let it be understood that Value and Capital (1939) was the work of J.R. Hicks, a 'neoclassical' economist now deceased; while Capital and Time (1973) - and A Theory of Economic History (1969) - are the work of John Hicks, a non-neo-classic who is quite disrespectful toward his 'uncle'. The latter works are meant to be read independently, and not to be interpreted ... in the light of their predecessor. (1975, p. 365)

Provocation aside, however, he unequivocally claimed that J.R. and John's oeuvre ran along the same track. His recollection of his first time in the U.S., in 1946, invited by Samuelson, Arrow, Friedman and Patinkin, is a case in point:

I did not know them, but they knew me; for I was the author of Value and Capital, which was deeply influencing their work. They regarded it as the beginning of their 'neoclassical synthesis' ... But I am afraid I disappointed them; and have continued to disappoint them. Their achievements have been great, but they are not in my line. (1979A [1983], p. 361)

Many authoritative commentators, such as Leijonhufvud (1977), Solow (1984), and Pasinetti (2008), deny the consistency and predictability of such a 'line'. As Hicks did actually change his publishing name from J.R. to John, they somehow turn the above-mentioned provocation into an assertion. On the other hand, Hicks experts ${ }^{1}$ complain that this name change is given undue consequence (Hamouda, 1993, p. xiv), since his 'intellectual output shows a surprising continuity ... The causal structure associated with decisionmaking and with the implementation of decisions has been central to his theoretical work' (Scazzieri and Zamagni, 2008, p. 4).

Manifold reasons lay behind these diverging views of the history of Hicks' thought, including his immense theoretical production ${ }^{2}$ and his prudent attitude towards the economic theory ${ }^{3}$. Yet the intuition inspiring the present study is that a good deal of this ambiguity is due to an element essential to his approach that, because of its rootedness, he barely disclosed (cf. Laidler, 1994, pp. 169-70), and little or nothing of which his commentators have brought out ${ }^{4}$.

The object of this article is the red thread of Hicks' oeuvre. His implicit perspective on the economic agent $(\S 3, \S 5)$ is shown to be the substructure underlying his research path and the common premise to his theories of markets $(\S 5)$, liquidity $(\S 6)$, capital $(\S 7)$, and risk (§8). Hicks' theory of the agent was intended to 
address the factual role of non-measurable risk (i.e., learning-management), and was primarily concerned with the price- and wealth-effects that the transaction costs - which fall under the two categories of the costs of learning (measuring risk) and the costs of moving (changing position) - entail for learning-induced behaviours.

\section{Paradise Lost}

Without sacrificing his literary passions for La Divina Commedia and Paradise Lost, Hicks graduated in 'Philosophy, Politics, and Economy' at Oxford in 1925. He wrote his dissertation, an empirical study on determination of wages, unblessed by any Marshallian baptism, the canon for English students of political economy. Although his best marks were in philosophy and politics (Hamouda, 1993, p. 7), in 1926 a greater demand for economists led him to the LSE to keep up his work on applied labour matters. As he was able to read Italian, French and German, the veteran of the Italian front, H. Dalton, exhorted him to study the theory of value in Pareto's Manuale. In addition, this theory appeared to be consistent with their department's prevailing ideology, championed by E. Cannan, of the reality of 'Paradise': only let the pricemechanism work, and a decentralized economic system will promptly produce optimal results.

Things did not look that simple any more as, in 1929, Robbins joined the LSE and directed Hicks to Böhm-Bawerk, Wicksell ${ }^{5}$, and Knight's Risk, Uncertainty and Profit, 'the background from which I began on the things which follow ... not yet even the Austrians' (1982, p. 11). Knight's book inspired his first important paper, 'The theory of uncertainty and profit' (1931), where we can spot something like a declaration of intent for a research programme inspired by Knight's point that the definition of the state of knowledge marks the beginning, not the end, of the relevant uncertainty:

If it is maintained that the doctrine of measurable risks gives a fair approximation to the truth, that may be admitted; but an approximation is of little use when it is no simpler and less illuminating than the truth itself. ... the grouping of measurable risks is simply a limiting case, and not a very important one, of the general principle of reduction. (1931, p. 175n)

Hicks appears to have been influenced by Knight's emphasis on ex ante non-measurable risk, the 
'Risk' ${ }^{6}$ that can be measured only ex post, in consequence of learning. Still, he was too young and ignorant of monetary theory to go further than allusions and hypothesise that the law of large numbers gave sufficient grounds to an aggregate IS equilibrium assumption (ib., p. 187f). The final draft of the article dated to 1930, when he set his Knightian concerns temporarily aside and arranged his earliest works in a book to give a boost to his academic career.

With The Theory of Wages (1932), Hicks 'started more or less where the new macroeconomics is now, although in that book he was concerned with stationary states and correct foresight rather than with steady-state growth and rational expectations' (Hahn, 1990, p. 544). When dealing with the working of competition (1932, pp. 58f), however, he admitted being perplexed with this 'Elementary economic analysis, which culminates in the determination of the conditions of equilibrium ... [because this] assumes, when it does deal with change, that the change has not been foreseen, but that, when it takes place, everyone can count on the new conditions being maintained'. As actual agents naturally consider new information unstable and uncertain, the equilibrium approach 'naturally leads to paradoxes', i.e., into the labyrinth.

As for a possible basis of a paradise-lost theory, Hicks suggested the 'costs of transference' (ib.). Whereas in equilibrium analysis they can be assumed away, in non-routine (learning) conditions, i.e., When a market is not in equilibrium, costs of transference cannot be spread over an indefinite period. Even if it is certain that the change will be a change for the better, it is not certain (and indeed it is highly improbable) that the new position will long continue to be the best attainable. It would be highly imprudent to change unless the cost of changing would be covered by the gain within quite a brief period. Costs of change, therefore, become a vastly more important influence on action tha[n] they would be under conditions of stationary equilibrium. (ib., p. 59, my it.)

In the meanwhile, Hicks was being initiated in monetary thinking through Hayek's seminars on Prices and Production at the LSE. Setting the stage for monetarism, Hayek's (1928) perfect foresight equilibrium, compatible with variations in relative prices but not with monetary disorders, displayed monetary policy as a major constraint on the self-regulation of an economic system. For Hicks, however, the factual role of non-measurable risk made such equilibrium, and any supposedly 'neutral' monetary policy, too paradisal to 
trust. He gave an outline of his first approach to money in a letter to Robertson: since money is there to finance learning-induced behaviours, i.e., to come to grips with non-measurable risk ${ }^{7}$, 'the use of money is inconsistent with economic equilibrium' (1973B [1977], p. 137).

\title{
3. First steps
}

\author{
That economic fluctuations arise, is sufficiently explained by Imperfect Foresight [non- \\ measurable risk], that they take the form that they do is to be explained largely by the close \\ connection between imperfect foresight [i.e., the use of a Store of Value] and the use of a Means \\ of Payment. (1933 [1982], p. 41)
}

The point of his first monetary article ${ }^{8}$ was that disequilibrium is due to the natural fact of Risk and not, as Hayek insisted, to the use of money. Disequilibrium being ineradicable, 'Monetary theory, in the strict sense, falls outside [stationary] equilibrium theory' and 'even a system of pure laisser-faire would be subject to monetary disturbances' (ib., p. 35).

A pivotal reading for the subsequent evolution of his monetary thinking was the German translation (1933) of Myrdal's Monetary Equilibrium (1931 [1939]). In search of a policy-rule to restore monetary stability, Myrdal cast aside Wicksell's natural equilibrium (conceivable only in routine conditions) and adopted temporary equilibrium ', 'a momentary market equilibrium in which price-expectations are taken as data' (1979A [1983], p. 360). Myrdal's eventual suggestion was to keep administered prices (interest rates) stable, so as to anchor market behaviours to robust price-expectations (Myrdal, 1931 [1939], p. 135; cf. Hicks, 1934 [1982], p. 44).

Hicks endorses Myrdal's suggestion in his 'Suggestion for Simplifying the Theory of Money' (1935A)the Simplification hereafter. This 'is usually read as a foundation of neoclassical monetary theory and a forerunner of portfolio selection theory. Undoubtedly, it is both things. Its concluding passages, however, ... show that it is something else, besides and ... beyond that' (De Cecco, 2008, p. 159). Indeed it is. The Simplification is based on the role of ex-ante non-measurable risk and focuses on learning-induced behaviours $^{10}$ : since '[unexpected] present prices affect the demand for money mainly through their effect 
on wealth and on price-anticipations' (1935A, p. 14n), Hicks adopted Myrdal's temporary equilibria assuming both endowments and price-expectations as given. As the combined effect of unexpected prices and unexpected variations in total wealth (themselves 'accompanied by a change in anticipations', ib., p. 16) on money demand can be ambiguous ${ }^{11}$,

The assumption which seems to me most plausible, most consistent with the whole trend of our analysis, and at the same time to lead to results which at any rate look realistic, is one which stresses the probable differences in the reactions of different members of the community. (ib., p. 17, my it.)

This is no less than the prelude to his later distinction between flexprice and fixprice market behaviours. In the Simplification, Hicks singled out two categories of agents, 'sensitives' and 'insensitives', in relation to the constraining power of transaction costs ${ }^{12}$ upon an agent's learning-induced demand for money. An agent's demand will vary in a fairly sensitive way when transaction costs are unimportant relative to his immediately disposable wealth (liquidity). If, as more generally is the case, his liquid wealth is not so great as to make transaction costs negligible, his induced demand will be rather insensitive.

All in all, liquidity constraints induce agents to refrain from price-effects and release wealth-effects on buffer stocks (ib., p. 17f). As trade between the sensitives gives rise to prominent and cumulative (procyclical) price-effects, it is (as in Myrdal) 'the insensitive people who preserve the stability of capitalism' (ib., p. 18). Therefore, 'we must not be led aside by a feeling that ... all would go well if we reverted to free trade and laisser-faire. In doing so, we are no better than the Thebans who ascribed the plague to bloodguiltiness' (ib.). Hicks was in fact invoking Sophocles to highlight a pivotal aspect ${ }^{13}$ of his thinking.

\section{The 'muddle'}

The idea that the temporary equilibrium method could somehow enable to analyse economic change as a learning process was one of the key aspects of interwar economics, and accordingly it was tested with disparate hypotheses on learning. For example, Lindahl $(1929,1930)$ had elegantly modelled a Wicksellian process driven by adaptive price-expectations in a single perfect market ${ }^{14}$. On this basis, Myrdal (1931, ch. 
6) had pointed up the virtues of imperfect markets, where current prices were not (sensitively) affected by current trades, although without providing any theory of their functioning (still unavailable at the time).

Given his emphasis on the stabilising role of the 'insensitives', the author of Value and Capital (VC hereafter) could not neglect the role of imperfect markets $(1939, \S 21.6)$. The $V C$ project, however, was the exploration of an altogether separate hypothesis, namely that Lindahl's approach to adaptive learning in a perfect market was extendable to $n$ perfect markets. Therefore, the first issue to address was not the management of learning, solved by hypothesis, but the aggregation of markets. The first step in that direction was an article (Hicks and Allen 1934) that secured aggregation within a restated Paretian setting. The first half of $V C$ and twenty-three of the twenty-five pages of its mathematical appendix, i.e., all that would lead to the neoclassical synthesis, stems from this paper.

The second step was 'Wages and interest: the dynamic problem' (1935B), where he aimed at embodying learning in a three-market barter model (the prototype of IS-LM and the last half of $V C$ ). The title reflects Hicks' awareness that the introduction of learning implied that the leading question of the model was 'the way in which the firm's production plan ... will be affected by changes in the prices and price-expectations which govern it' (1935B [1982], p. 73). He thus immediately realized, as Keynes (1936) would, too, that consistent comparison of a sequence of two temporary general equilibria required the absence of learning in between, i.e., no 'false' trading (with associated wealth-effects)-in two words, perfect transparency. So,

it is very important to be clear first of all that the changes with which we are concerned are purely hypothetical changes. We are still on our first Monday; we are examining the differences between the production plan actually adopted and that which would have been adopted if prices or price-anticipations had been different. (ib.; my it.)

This restriction to counterfactual logic rules out adaptive learning and is transmitted to the $V C$ model, where in fact price-expectations are eventually assumed elastic to current prices (ch. 20), i.e., in a system of perfect markets, to current learning! So, as it involved an improper combination of past ignorance (learning process) and present omniscience (general equilibrium), the $V C$ model proved inconsistent with its own design (adaptive general equilibrium). So to speak, the cart (aggregation) was placed before the horse 
(learning); in the Simplification, instead, things were set to rights.

I sometimes feel, looking back, that it ought to have been my duty, after writing [the Simplification], to have abandoned all other interests [my it.], and to have devoted myself entirely to pushing forward along the road on which I had taken first steps. ... I allowed myself to be distracted, first by the writing of Value and Capital ... and then by the General Theory of Keynes. (1982, p. 9)

Both his Lindahlian $(V C)$ and Keynesian interests proved 'distractions' from his more fundamental Myrdalian (Simplification) one. His interest in Keynes' book was due to the fact that Keynes deemed Hicks the best on the market to valorise the Liquidity Preference doctrine, and asked him to be its first reviewer (cf. 1973B [1977], p. 142). Yet, regarding Keynes' monetary approach as a simplification of his Simplification, Hicks (1936) focused on the multiplier.

Since it is a purely real single-period effect enclosed within two monetary (temporary) equilibria, the multiplier can only be determined as a perfect transparency effect ${ }^{15}$ (cf. Keynes, 1936, p. 50). For it also to be effective, the extra incomes of the wage-good sector (out of the expenditure of the new employees in the capital-good sector) need to be reinvested; hoarding, in fact, would entail an ineffective (precautionary) demand. As the combined effect of time-to-build and perfect transparency is a nominal adjustment (1936 [1982], pp. 91, 93f), Hicks remarked that Keynes was overlooking a third condition for the multiplier to be effective, namely that the supply of consumption-goods be very elastic. This, however, clashes with the corollary of the first condition (perfect transparency) that 'the period [is] taken short enough for us to be able to neglect changes in expectations within it' (ib., p. 87n). Thus Hicks' first impression was that, with its inattention to both non-measurable risk and the time-to-build, Keynes' new technique was 'conservative: more conservative than in the Treatise' (ib., p. 99).

Six months later (Sep. 1936) the Econometric Society met in Oxford. Hicks was invited to translate Marshall's relations into Keynes's: 'Since our purpose is comparison' (1937, p. 148), he set out the IS-LM model. Having the above-mentioned 'conservative' aspect in mind, his scepticism about IS-LM is not surprising: the presumed equivalency of marginal cost and marginal productivity - as in the same General Theory itself - resulted in the neglect of both non-measurable risk and the time-to-build ('all sorts of 
questions about the timing of the processes under consideration', ib., p. 158). The IS-LM, just like its prototype (1935B) and VC, could only deal with 'purely hypothetical changes'. Also Keynes' (1936) method, 'an admirable one for analysing the impact effect of disturbing causes' (1936 [1982], p. 87), could only yield 'hypothetical results' (ib.), counterfactual recommendations. Moderns call them stabilization policies.

\section{Learning and Planning}

An article (1956) practically inaccessible for 26 years was, Hicks wrote, 'from my own point of view, one of my most important works' ... With it the muddle ... was at last cleared up. At last I could go ahead' (1982, p. $217)^{16}$. The object of $V C$ being change, not stability, its celebrated definition of a dynamic theory was to be censured $^{17}$ : dynamics is simply the 'theoretical analysis of the process of economic change' (1956 [1982], p. 220), but comparative statics is all we need whenever a process of change is not learning-driven (a mechanical one). These two simple conclusions marked the clearing up of his Lindahlian and Keynesian interests (cf. ib., p. 221-31) and of 'the muddle' (1976B [1982], p. 289) they had led him to.

Before they can affect behaviour, mistakes need to be identified and interpreted. It is therefore proper to single out two kinds of theories - one relative to economic history, the other to economic policy approaching mistakes ex-post and ex-ante respectively, with the former however functionally prior to the latter. The history-related economic theory aims at explaining co-ordination failures, i.e., one's mistakes due to inconsistencies with others' prospects and plans. Co-ordination failures can be discerned counterfactually, using ex-post perfect foresight performance as a measuring stick to assess the mistakenness of actual past expectations. Since measures derived in this way are perfectly robust for a single period, Hicks named this theory 'Single Period Theory'.

Conversely, the policy-related economic theory aims at explicating 'the effects of the events of a first period upon the expectations and plans which themselves determine the events of its successors' (ib., p. 223, my it.), i.e., how mistakes affect learning and planning ${ }^{18}$. 
up the central dynamic issue - how to superimpose the pattern of change, which is one timepattern, upon the underlying pattern of capital-using production, which is another. Though there are ways of avoiding this issue, they are bound to result in depriving the behaviour under study of its purposive character, so that the economic system is reduced to a mere mechanism. (1956 [1982], p. 221)

This 'central dynamic issue' - the interplay of learning ('the time-pattern of change') and planning ('the underlying pattern of capital-using production') - would be the centre of attraction in his following theoretical explorations. This interplay can be conveniently approached with the special case of an activity that needs no planning, i.e., the exhaustion of existing arbitrage opportunities (speculation), which is precisely what the 'sensitives' of the Simplification do.

Sensitives try to improve their position by 'beating the gun' (moving as fast as possible) as soon as any new measure (information) becomes available. The only precondition to be sensitive is to be free from liquidity constraints, so as to keep transaction costs irrelevant over time (cf. 1932, p. 59: 'spread over an indefinite period'). As the decisional temporal frame of a sensitive is a shortest possible period (the edge of a point of time), a sequence of his moves can be analysed via the ordinary temporary equilibrium model, i.e.,

the regular theory of price-determination in a speculative market ... Here, at any given moment, there are in existence given stocks of the commodity; but, over a period, these stocks are being added to by production and being drawn by consumption. At a moment of time, or over any sufficiently short period of time, these additions and subtractions can be taken as negligible; price is therefore determined by the Liquidity Preference of the dealer, or, in other words, by their willingness to hold stocks ... Thus, at each moment, price is determined by the condition that demand to hold equals the available supply. (ib., p. 227, my it.)

As the speculator has no liquidity constraints, speculation analysis can do without the transaction costs (wealth-effects) associated with stock disequilibria. A shortcut for future periods is thus licit: as all the stocks he/she holds are voluntary, a speculator's liquidity preference depends on price-expectations only. Since a speculator's learning-management strategy (reacting instantly to changes in available information) 
is essentially adaptive, the speculator can pay no heed to ex-ante non-measurable risk and analysis of speculative dynamics can be carried out with 'self-contained periods' (1965, pp. 31f), along flexprice lines.

Such a simplified setting is no longer licit with the general case of an operator who has to face liquidity constraints. Someone who cannot afford the speculative (adaptive) way of life can improve his/her situation only by producing new, currently non-existing, opportunities (innovation, cf. n. 4). Inputs (spending) preceding outputs (earnings), 'productive' moves are characterized by a certain time span (the time-to-build) during which new capacity is being built (or, more generally speaking, learnt). The relative construction costs (anticipations) are a kind of transaction costs having a sinking effect on performance ${ }^{19}$ : it is only when capacity is ready for use that sales allow a producer to get back on his/her feet and finally improve his/her situation.

Due to the time-to-build, a productive activity needs to be based on planning. Due to the nonmeasurable risks impending all along the planning span, a producer needs a proactive approach to learningmanagement. As a matter of fact, in the general case of the producer, an adaptive (i.e., speculative) pricing strategy (i.e., letting current trade determine the selling-price without adjustments in the capital structure) is hardly sustainable. The invisible hand is an actual, visible threat to his/her running plan. Since the risks relative to wealth-effects are more manageable than those relative to price-effects, in non-speculative markets - 'Q-markets' (1956), or 'Fixprice markets' (1965) - suppliers manage their selling prices.

As for analysis of a sequence of productive moves, what is needed is a model whose 'characteristic nexus' is a 'chain of causation, working from sales via stocks to inputs' (1956 [1982], p. 228). Whenever actual sales differ from desired (planned) sales, undesired stocks pile up, and their relative wealth-effects can prevent a producer from disposing of the liquidity required to keep his plan viable. Whenever a revision of the plan is undertaken, the sinking effect of new anticipations (inputs) is carried over at least beyond the time-to-build. In both links of the chain, the effects of mistakes (on learning and planning) are thus carried over beyond the single period. The time structure of productive activity is therefore consequential ${ }^{20}$, and the (general) analysis of productive dynamics cannot be carried with self-contained periods.

In dealing with the general case of economic agent, both the positive and normative powers of a flexprice model are weak: 'Where the Value and Capital analysis goes wrong is that it treats an exceptional 
type of market [i.e., a speculative market] as if it were the normal case' (1956 [1982], p. 225). The temporary equilibrium method can only apply to operative periods so short that future information (nonmeasurable risk) can be safely left out of account (e.g., present-day High-Frequency Trading).

In the general case, on the other hand, non-measurable risk cannot be disregarded. The structure of planned activity is revised only when the costs of a given change are valued less than its benefits. Since both investment and disinvestment take time, appraisal of an opportunity for revision involves conjecture about the extent to which future learning episodes and relative wealth-effects can, within the planning span, affect its course. In this sense, the continuation (viability) of a planned activity is what the general agent is essentially involved in, which is why Hicks called the policy-related economic theory 'Continuation Theory'.

The viability (continuation) question calls for a shift of emphasis from final positions (equilibrium conditions) to initial positions (transaction costs): a producer is always facing 'the double problem: on the one hand he must estimate what the course of demand will be [i.e., learning], and on the other he must correct the excesses and deficiencies of stock that result from past mistakes [i.e., moving]' (1965, p. 95). Decision-making is in fact made up of two stages, learning and moving. Both stages lay at the core of Hicks' explorations into money and capital. In monetary theory he played up the aspect of learning, in capital theory that of moving.

\section{Planning and Liquidity}

After clearing up the muddle, Hicks was in a position to point out the explanandum of a proper notion of liquidity:

a worse than 'expected' outcome must be dreaded more than a better than 'expected' outcome is desired. This is not because of any abstract 'law of diminishing marginal utility'; it is because of the impact which such unfavourable outcomes may have upon the non-liquid elements in the situation (things that may happen on the side of liabilities or on the side of other, non-liquid, assets). (1962, pp. 793f) 
As a preliminary step (1962, p. 789ff), Hicks recalled Keynes' first notion of liquidity, which he thereafter stuck to: an asset is more liquid than another if 'more certainly realisable at short notice without loss' (Keynes, 1930, II, p. 67). Liquidity is therefore a matter of 'the difference between the current market price of the asset and what it might fetch if it were to be disposed of at an unfavourable moment' $(1989$, p. 62), i.e., of nominal stability: 'if the price is very variable, the asset is still imperfectly liquid-because ... the risk of loss remains' (1974B, p. 43).

Yet nominal stability was not the end of the liquidity story. That is why, to highlight the impact of non-measurable risk (learning) upon 'the non-liquid elements in the situation', he rather (1967, pp. 38f) drew attention to the fact that, from the accounting point of view, assets can be classified as running (required for current activity), reserve (held for future emergencies), or investment assets (held for a future profit), and focused on two types of assets, money $(M)$ and productive capacity $(T)$. Let $T_{1}$ be capacity in use, $T_{2}$ idle capacity, and $T_{3}$ capacity under construction (cf. time-to-build). Whereas $T_{2}$ can protect a planned $T_{1}$ against some specific measurable risk, the need to hedge against non-measurable risks calls into question the (greater) liquidity of the monetary asset: $M_{3}$ is speculative demand, $M_{2}$ precautionary demand, and $M_{1}$ 'the money requirement for ... the general pattern of production (or consumption) on which the unit is engaged' $(1967$, p. 40$)$, i.e., the assets required to back the running liabilities of that pattern.

This 'transactions requirement' (ib., p. 37) is not exactly 'a voluntary demand, like the demand for commodities, which could be forced-even with an effort-into the mould of marginal utility theory ... in its nature $\left[M_{1}\right]$ is a disequilibrium, not an equilibrium phenomenon' (ib., p. 14f). In marginal utility theory, just as in other equilibrium approaches, the demand for an asset is ideally sensitive to learning episodes because non-measurable risks are assumed away. Equilibrium approaches only apply to the adaptive strategies of speculative activity where transaction costs are actually irrelevant. In the general case of liquidity constraints, instead, the liquidity required to financially sustain a running plan can only be rather insensitive: variations in $M_{1}$ will only follow changes in planning, but - due to the (dis)investment costs (i.e., the costs of transforming plans) - not all learning episodes are liable to affect a running plan. 
securities with positive probable yield, as the [equilibrium] theory would seem to have instructed him to do ... The reason why he does not do so is clear; it is simply the cost of making transactions, which economists so easily leave out ... Obviously it is transaction cost which limits [risk] 'spread'; but it does much more than that. It introduces another qualification which transforms the whole theory ... If transaction costs were zero, it would in fact be only necessary for the investor to look ahead to the 'next decision point' ... He could behave, all the time, as if there were only one investment period of which he needed to take into account. (ib., pp. 31f)

We can conveniently approach Hicks' views on risk (learning) and liquidity (money) by starting, once again, with the special case of the speculator. Thanks to the absence of liquidity constraints the speculator can afford a peculiar learning-management strategy making the value of the portfolio maximum and, at the same time, the most protected (to the extent allowed for by the quality of information). The speculator adapts specularly to new information, as a mirror image, unconditionally and without delay. The speculative life-style is 'fluid' (1982, pp. 258ff), solely concerned with the current period $\left(M_{1}=0, M_{2}=\right.$ $\left.0, M_{3}=L\right)$, as if he/she were about to cash everything in.

The portfolio selection theory is [essentially] concerned with ... a single choice; and that is the point, I maintain, where liquidity slips through. For liquidity is not a property of a single choice; it is a matter of a sequence of choices, a related sequence ... There is an element in risk-bearing over time which escapes from the conventional presentation, [i.e., whether] the choice admits of flexibility ... the flexibility that is given by the market. (1974B, pp. 37-41)

Liquidity slips through because the time structure of productive activity is consequential. A producer is primarily interested in avoiding falling short of his transaction requirement, i.e., in minimizing the costs of learning management: 'The Liquidity theory-Liquidity theory proper-will tell the story entirely in terms of financial running assets and financial reserve assets' (ib., p. 49), and speculative demand is of no consequence ( $\left.L=M_{1}+M_{2}, M_{3}=0\right)$. Conversely, $M_{3}$ is all-important in the special case of the speculative activity and, of course, in portfolio selection.

The costs of changing the structure of liabilities (transforming plans) make $M_{1}$ neither immediately nor directly sensitive to learning and incentives. Just as any financial windfall, 'like surplus stocks of 
materials, automatically becomes a reserve asset' (1967, p. 40), so pitfalls will be more conveniently financed out of a reserve fund $\left(M_{2}\right)$, e.g. an overdraft facility. A sequence of pitfalls implies accumulation of an undesired (unplanned) stock of $T_{2}$ bringing about, as a wealth-effect ${ }^{21}$, a fall in $M_{2}$. This after-effect is symptom of a diminution in an agent's capacity to sustain the liabilities of his running plan, i.e., in the flexibility of his/her initial position ${ }^{22}$. Liquidity (i.e., the flexibility of initial positions) is essential to the management of a process of change: to a 'producer', $M_{1}$ are necessary to improve position, and $M_{2}$ are necessary to cope with non-measurable risk (learning management). Liquidity affords both the time-tolearn (to notice mistakes, interpret them as co-ordination failures, and conjecture about opportune reactions) and the time-to-move (to react). So, though it yields no interest, liquidity yields something vital to the production of new opportunities: liquidity yields Time.

\section{Liquidity and Movement}

Whereas Hicks' monetary theory was mainly dealing with learning, i.e., 'the time-pattern of change', his capital theory was mainly designed to focus on 'the time-pattern of capital-using production'. In Capital and Growth (1965) he considered both Keynesian and Walrasian approaches variations of that 'Method of Sectorial Disintegration' by which 'The accounting distinction between Consumption and Investment is converted into an industrial division' (1973C, p. 5). With Capital and Time (1973C, CT hereafter) and a number of related articles, instead, he returned to the Austrian (Böhm-Bawerkian) field. However uncultivated it may have been since the days of Value and Capital (1939, chs. 15-17), he always thought it was the best to tackle 'the central dynamic issue' (1956).

On one hand, since it focuses attention on the sectorial structure of activity, the Walrasian approach plays up the vertical (temporal) structure only indirectly, by derivation from a lagged production function. In doing so, however, 'the process is lost to sight' (1973C, p. 13). The materialist (Walrasian) concept of capital is therefore at home in single-period theory, i.e., in economic history (1970, p. 257), while in continuation theory it is 'very hard to handle' (ib.). For the latter theory the Austrian approach is by far preferable, as its forte is to point out that capital is 'an expression of sequential production. Production has 
a time-structure, so capital has a time-structure' (1973A [1983], p. 100).

The Austrian image of a technique is an $n$-period duplex flow of a homogeneous input $(a)$ and a homogeneous output $(b)$ :

$$
\left(a_{0}, a_{1}, \ldots, a_{n} ; b_{0}, b_{1}, \ldots, b_{n}\right)
$$

with $b_{0}=\cdots=b_{n-1}=0$, and $b_{n}=1$. Via a slight amendment, Hicks translated the Austrian technique into the neo-Austrian plan, where a temporal stream of financial requirement $\left(a_{t}\right)$ is sustaining a temporal stream of productive capacity $\left(b_{t}\right)$. The only prerequisite for a productive process to be capital-using is anticipation $\left(b_{0}=0\right)$. In accounting terms, there is investment until capacity is under construction (as long as $\left.b_{t}=0\right)$; disinvestment (consumption) when capacity is thereafter being used $(1973 \mathrm{C}, \mathrm{p} .5)$.

While the neo-Austrian representation of a plan calls into question both sides of the balance sheet $a_{t}$ are liabilities, $b_{t}$ assets - the nature of capital is the same as in the 'classical', old-Austrian theory: capital is a wage fund, a monetary fund acting as collateral for the liabilities of a business ${ }^{23}$. And yet risk and liquidity do not play an explicit role in his neo-Austrian theory. The CT model is based on a Full Performance hypothesis (1973C, pp. 52-55) that obviously implies perfect foresight. As non-measurable risk and learning are ruled out, money is inessential, output the standard of value. Still, the $C T$ project was a building block of a continuation theory in that it definitively fixed his early objection (1933) to Hayek's proto-monetarist views (cf. §3): 'It is not true that by getting rid of money, one is automatically in equilibrium' (1973C, p. 133)-however equilibrium is conceived.

'On the Austrian approach, one can start out of equilibrium (so far as inputs and outputs are concerned) straight off' (1970, p. 258): with the CT model it is possible to show an initial position that is out of equilibrium as far as the time-to-build is concerned, i.e., an initial position that is under the pressure of a wealth-effect implied by an attempt at moving in reaction to a learning episode, and leaving out of account the pressure implied by learning expenditure. The model was vertically integrated (paying no heed to sectorial disintegration) because Hicks focused on the dynamic wealth-effects of anticipations (vertical transaction costs, costs of investment), 'more violent and therefore more difficult' (1973C, p. 133) - read: more fundamental - than the single-period wealth-effects due to the costs of market transactions (horizontal transaction costs, or costs of speculation). 
The theoretical and political moral of Hicks' neo-Austrian capital theory was that, even with perfect foresight, any attempt at moving, if a slowdown of activity is to be avoided, needs to be buttressed by an influx of resources exogenous to the running plan ${ }^{24}$ : transaction costs mark the way of change, but liquidity is the flywheel of the actual course of change. Having such steering in mind - and alluding to his halfhearted use of the Full Performance hypothesis (just a ceteris paribus clause) - Hicks repeatedly quoted J.S. Mill's words:

this perpetual non-employment of a large proportion of capital is the price we pay for the division of labour. The purchase is worth what it costs, but the price is considerable. (Mill, 1874 [1974], p. 56)

\section{Risk and Uncertainty}

Hicks' liquidity theory focuses on the transaction requirement of a plan of action $\left(M_{1}\right)$, the same object of his investigations in capital theory, and a buffer stock for the sake of non-measurable risk management $\left(M_{2}\right)$. We shall devote these last pages to one of Hicks' explorations in risk theory which concerns these distinct domains of liquidity theory and which holds a message offering conclusive confirmation of the thesis proposed in the present article. Hicks rephrased his 'Second Theorem in Risk Theory' three times (1977, pp. 166-76; 1982, pp. 251-56; 1989, pp. 137-42), lastly in appendix to his last book, A Market Theory of Money:

I introduce it here, in spite of the very un-Knightian assumptions on which it is basedassumption I do not much care for myself-because it brings out a point, which in the end does not seem to depend on them, and which should be quite a help towards understanding what I am saying in this book. So I want to emphasize that my acceptance of these assumptions is only provisional. (1989, p. 137, my it.)

The assumptions are indeed the usual, 'speculative' ones: a price-taker is allocating a given sum into the maximum-expected-utility combination of $n$ securities under certainty-equivalence conditions. Even the utility function is 'speculative', i.e., the distribution among securities is independent of the scale of 
operations (wealth effects): such is the case when $u(y)=B-\frac{A}{h-1} y^{-(h-1)}$, where $A$ and $B$ are positive constants and $h$ is the reciprocal of the price-elasticity of the demand function for the bundle of securities. In the elastic case $(h<1)$, we have a St. Petersburg (risk-neutral) utility function s.t. $\lim _{y \rightarrow 0} u(y)=B$ and $\lim _{y \rightarrow \infty} u(y)=+\infty$, with $u^{\prime}(y)<0$ throughout; in the inelastic case $(h>1)$, a Ramseyian function s.t. $\lim _{y \rightarrow 0} u(y)=-\infty$ and $\lim _{y \rightarrow \infty} u(y)=B$. Hicks focused on the inelastic case because the Ramseyian agent is risk-averse, i.e., aware of the existence of non-measurable risks ${ }^{25}$.

The zero point is the 'disaster point', a position with the greatest finite bankruptcy risk. Its minusinfinity utility means that a speculator aiming at continuation of his business always manages to avoid this point. Via a slight amendment, Hicks generalised this setting to the general case of the producer ${ }^{26}$ : $u(y)=B-\frac{A}{h-1}(y-c)^{-(h-1)}$, where $c$ is a non-negative constant and, of course, the disaster point, too. In the generalised case, this point can be linked to the (current) transaction requirement of the producer's running plan and interpreted as a totally illiquid position where continuation of that plan becomes impossible (so that the running plan must be 'truncated').

As far as possible, the disaster point is kept at a healthy distance: whoever is hooked within a safe distance will be inclined to demand more liquid securities, giving up those less liquid securities (or property claims on productive capacity) whose value may be lowest in some eventualities, and devoting any windfall to repletion of the reserve fund $\left(M_{2}\right)$. Such may formally be the case - with a small development of Hicks' formulation having the plus to imply that utility itself is an aspect of risk-bearing and that the utility function is indeed a flexibility function - whenever $u(y-c)<0$, i.e., as soon as a truncation risk becomes measurable.

Substantially, however, the principle is much more general than that: in a continuation perspective, liquidity constraints make operators 'fairly insensitive to price anticipations ... [so that, with given commitments (cf. 1982, p. 255),] most of the incentive to reduce their demand for money when events turn out more favourably will be missing' (1935A, p. 17). From a micro-foundation perspective, that 'the [involved] assumption of a rigid demand for money snaps the connecting link between money and prices' (1935A, p. 17) amounts to saying that 
out of a large population of persons and businesses ... for the group as a whole there must be a positive wealth effect ... This is my second theorem. It is very near to what I conjectured, many years ago, in [the Simplification]. It was there no more than a conjecture; the Bernoullian analysis, here presented, gives it a little more substance. The qualification that it has introduced - that the bias in the wealth effect is a matter of the strength (or comfort) of the operator's position - will stand, whether or not we accept the Bernoullian approach; but without that approach, it would be hard to bring it out so clearly. (1982, p. $255 f$, my it.)

That wealth effects are a matter of liquidity constraints is precisely what 'should be quite a help towards understanding what I am saying in this book' (1989, p. 137). That these effects are the stronger the liquidity-constrained an agent becomes is also the essential property of Hicks' view of the economic agent we have, throughout these pages, maintained to be Hicks' thread.

\footnotetext{
I am at last in a position to go back at Knight. His major distinction, between measurable risks, based on cardinal probabilities (for which there is evidence) and what he calls true uncertainties, which are not so based, I fully accept. Indeed I would now attach much more importance to it than I did in my first contribution to the subject [1931] ... That I hope I will have made clear in what precedes. The chief criticism I would now make of him is that his terminology, which has greatly influenced many subsequent writers, is rather confusing [cf. n. 6]. Our disaster point should help to get it straight. For it suggest that what is needed is a four-way, not a two-way classification. (1989, p. 141f, my it.)
}

Hicks crosses Knight's distinction with that of risky and unrisky choices, depending on whether a truncation risk is probabilistically implied or not. So, besides (1) measurable risky choices, mitigable with a form of insurance, and (2) non-measurable risky choices, 'which probably match the true uncertainty of Knight' (ib., p. 142), we have (3) measurable non-risky choices, 'like buying the ticket for a lottery, where the loss involved in not getting a prize is easily bearable' (ib.), and (4) non-measurable non-risky choices, 'such as one might think to be involved in the ordinary running of a business' (ib.).

In our interpretation, the non-riskiness of a choice highlights its prudential character, that is the Ramseyian attitude of its maker. He/she aims at moving on 'flexible' positions $(0<u(y-c)<B)$, where any truncation risk is prevented from becoming 'measurable' (appreciable). In particular, with given 
commitments and given information, the Ramseyian agent aims at diminishing the distance from $B$ of his/her position. Yet, in the general case of a producer's (i.e., an 'innovative') choice the non-riskiness of the move is itself non-measurable (uncertain), due to the non-measurable risks impending all the time it takes to move to his/her desired position. It is only in the special case of speculative choices out of liquidityunconstrained portfolios (or parts of them) that the non-riskiness of a move becomes measurable (ascertainable).

His analogy with the lottery is indeed to the point as the fact that loss can be borne so lightly has to do with to the absence of liquidity constraints. The average economist's presumption that so-called black swans (non-measurable risks) can be neglected roots in this absence. Yet Hicks' equivocal position in the history of $20^{\text {th }}$ century economic theory was due not only to the paradisal standpoint of the average economist, where the lottery (speculation) is perceived as general form of the economic problem, but also to his scant success in displaying the basics of his opposite perspective. This is the task we have attempted in these pages. 


\section{References}

Amendola, M. 1991. Liquidity, Flexibility and Processes of Economic Change, in McKenzie and Zamagni, 1991, pp. 33351

De Cecco, M. 2008. Hicks's notion and use of the concepts of fix-price and flex-price, in Scazzieri, Sen and Zamagni, 2008 , pp. $156-63$

Donzelli, F. 2010. Hicks on Walrasian equilibrium in the 1930 s and beyond, Working Paper, http://www.economia.unimi.it/uploads/wp/DEAS-2010_39wp.pdf

Hagemann, H. and Hamouda O.F. (eds) 1994. The Legacy of Hicks, London and New York, Routledge Hagemann, H. and Scazzieri, R. (eds) 2008. Capital, Time and Transitional Dynamics, London, Routledge

Hahn, F.H. 1990. John Hicks the theorist, Economic Journal, vol. 100, no. 401, pp. 539-49

Hamouda, O.F. 1993. John R. Hicks: The Economist's Economist, Oxford, Blackwell

Hayek, F.A. von 1928. Das intertemporale Gleichgewichtssystem der Preise und die Bewegungen des Geldwertes, Weltwirschaftliches Archiv, Bd. XXVIII, pp. 33-76; English tr. in Hayek, F.A. 1984, Money, Capital \& Fluctuations. Early Essays, edited by R. McCloughry, London, Routledge \& Kegan Paul

Hayek, F.A. von 1931. Prices and Production, London, Routledge

Hey, J.D. 1994. Risk and uncertainty, in Hagemann and Hamouda, 1994, pp. 187-99

Hicks, J.R. 1931. The theory of uncertainty and profit, Economica, no. 32, pp. 170-89

Hicks, J.R. 1932. The Theory of Wages, London, Macmillan

Hicks, J.R. 1933. Gleichgewicht und Konjunktur, Zeitschrift für Nationalökonomie, IV. Bd., 4. H., pp. 441-55 Equilibrium and the trade cycle, Economic Inquiry, vol. 18, no. 4, October 1980, pp. 523-34

Hicks, J.R. 1934. Reviewed Work(s): Beiträge zur Geldtheorie by F. A. von Hayek, Economica, vol. 1, no. 4, pp. 479-83 Hicks, J.R. 1935A. A suggestion for simplifying the theory of money, Economica, vol. 2, no. 5, pp. 1-19 Hicks, J.R. 1935B. Wages and interest: the dynamic problem, Economic Journal, vol. 45, no. 179, pp. 456-68 Hicks, J.R. 1936. Mr Keynes's theory of employment, Economic Journal, vol. 46, no. 182, pp. 238-53

Hicks, J.R. 1937. Mr Keynes and the "classics", Econometrica, vol. 5, no. 2, pp. 147-59 
Hicks, J.R. 1939. Value and Capital: an inquiry into some fundamental principles of economic theory, Oxford, Clarendon Press

Hicks, J.R. 1946. Value and Capital: an inquiry into some fundamental principles of economic theory, Second edition, Oxford, Clarendon Press

Hicks, J.R. 1956. Methods of dynamic analysis, in Twenty-five Economic Essays in Honour of Erik Lindahl, Stockholm, Ekonomisk Tidskrift

Hicks, J.R. 1962. Liquidity, Economic Journal, vol. 72, no. 288, pp. 787-802

Hicks, J.R. 1965. Capital and Growth, Oxford, Clarendon Press

Hicks, J.R. 1967. Critical Essays in Monetary Theory, Oxford, Clarendon Press

Hicks, J.R. 1970. A neo-Austrian growth theory, Economic Journal, vol. 80, no. 318, pp. 257-81

Hicks, J.R. 1973A. The Austrian theory of capital and its rebirth in modern economics, in Hicks J.R. and Weber W. (eds), Carl Menger and the Austrian School of Economics, Oxford, Clarendon Press, pp. 190-206

Hicks, J.R. 1973B. Recollections and documents, Economica, vol. 40, no. 157, pp. 2-11

Hicks, J.R. 1973C. Capital and Time: A Neo-Austrian Theory, Oxford, Clarendon Press

Hicks, J.R. 1974A. Capital controversies: ancient and modern, American Economic Review, vol. 64, no. 2, pp. 307-16

Hicks, J.R. 1974B. The Crisis in Keynesian Economics, Oxford, Basil Blackwell

Hicks, J.R. 1975. Revival of Political Economy: the old and the new, reply to Harcourt, Economic Record, vol. 51, no. 3, pp. $365-7$

Hicks, J.R. 1976A. 'Revolutions' in Economics, in S.J. Latsis (ed), Method and Appraisal in Economics, Cambridge, CUP, pp. $207-18$

Hicks, J.R. 1976B. 'Some questions of time in economics', in A.M. Tang et al (eds), Evolution, Welfare and Time in Economics: Essays in Honour of Nicholas Georgescu-Roegen, Lexington, MA: Heath, Lexington Books, pp. 135-51 Hicks, J.R. 1977. Economic Perspectives: Further Essays on Money and Growth, Oxford, Clarendon Press Hicks, J.R. 1979A. The formation of an economist, BNL Quarterly Review, no. 130, pp. 195-204 Hicks, J.R. 1979B. Causality in Economics, Oxford, Basil Blackwell Hicks, J.R. 1982. Money, Interest and Wages: Collected Essays on Economic Theory, vol. II, Oxford, Basil Blackwell 
Hicks, J.R. 1983. Classics and Moderns: Collected Essays on Economic Theory, vol. III, Oxford, Basil Blackwell

Hicks, J.R. 1985. Methods of Dynamic Economics, Oxford, Clarendon Press

Hicks, J.R. 1989. A Market Theory of Money, Oxford, Clarendon Press

Hicks, J.R. 1990. The unification of macroeconomics, Economic Journal, vol. 100, pp. 528-38

Hicks, J.R. and Allen, R.G.D. 1934. A reconsideration of the Theory of Value. Economica, vol. 1, no. 1, pp. 52-76 (Part I) and no. 2, pp. 196-219 (Part II)

Jones, R.A. and Ostroy, J.M. 1984. Flexibility and Uncertainty, The Review of Economic Studies, vol. 51, no. 1, pp. 13-32

Keynes, J.M. 1930. A Treatise on Money, The Collected Writings of J.M. Keynes, voll. V and VI, London, MacMillan, $1971-2$

Keynes, J.M. 1936. The General Theory of Employment, Interest and Money, The Collected Writings of J.M. Keynes, vol. VII, London: MacMillan, 1973

Klaes, M. 2000. The history of the concept of transaction costs: neglected aspects, Journal of the History of Economic Thought, vol. 22, no. 2, pp. 191-216

Laidler, D.W. 1994. Hicks's later monetary thought, in Hagemann and Hamouda, 1994, pp. 163-73

Leijonhufvud, A. 1979. Review of Hicks (1977), Journal of Economic Literature, vol. 17, no. 2, pp. 525-528

Lindahl, E. 1929. Prisbildnings problemets uppläggning från kapital-teoretisk synpunkt, Economisk Tidskrift, pp. $31-105$

Lindahl, E. 1930. Penningspolitikens Medel. Skrifter utgivna av Fahlbeckska Stiftelsen, Malmö, Förlagsaktiebolaget i Malmö Boktryckeri

Lindahl, E. 1939. Studies in the Theory of Money and Capital, London, George Allen \& Unwin Ltd; New York, Augustus M. Kelley, 1970

McKenzie, L.W. and Zamagni S. (eds) 1991. Value and Capital Fifty Years Later (Proceedings of a Conference held by the International Economic Association at Bologna, Italy), London, Macmillan

Mill, J.S. 1874 [1974]. Essays on some unsettled questions of political economy, Second edition, N.Y.C., Augustus M. Kelley

Myrdal, G. 1931. Om Penningteorisk Jämvikt ; (German ed.) Der Gleichgewichts Begriff als Instrument der Geldteoretischen Analyse, 1933; (English tr. on German ed.) Monetary Equilibrium, first ed. 1939; (reprints) New 
York, Augustus M. Kelley, 1962, 1965

OEP, 1984. Oxford Economic Papers, vol. 36, Supplement: Economic Theory and Hicksian Themes

Pasinetti, L.L. and Mariutti, G. 2008. Hicks's 'conversion' - from J.R. to John, in Scazzieri, Sen and Zamagni, 2008, pp. $52-71$

Puttaswamaiah, K. (ed) 2001. John Hicks: His Contributions to Economic Theory and Application, New Brunswick (US) and London, Transaction Publishers

Scazzieri, R., Sen, A. and Zamagni, S. (eds) 2008. Markets, Money and Capital: Hicksian Economics for the Twenty-First Century, Cambridge, CUP

Scazzieri, R. and Zamagni, S. 2008. Between theory and history: on the identity of Hicks's economics, in Scazzieri, Sen and Zamagni, 2008, pp. 1-37

Solow, R.M. 1984. Mr Hicks and the Classics, in OEP, 1994, pp. 13-25

Wolfe, J.N. (ed) 1968. Value, Capital and Growth, Essays in Honor of Sir John Hicks, Chicago, Aldine 


\section{Footnotes}

1. Most of the literature concerned with Hicks' works is to be found in these collections: Wolfe, 1968; OEP, 1984; McKenzie and Zamagni, 1991; Hamouda, 1993; Hagemann and Hamouda, 1994; Puttaswamaiah, 2001; Scazzieri, Sen and Zamagni, 2008; Hagemann and Scazzieri, 2009.

2. The whole bibliography of Hicks' oeuvre is in Hagemann and Hamouda, 1994, pp. 260-70. It counts about 230 titles covering every angle of economic theory.

3. He never committed much to this or that school of economic thought, and considered economics 'a discipline, not a science' (cf. 1983, pp. 365-75) because 'since it is a changing world that we are studying, a theory which illumines the right things at one time may illumine the wrong things at another ... There is, there can be, no economic theory which will do for us for everything we want all the time' (1976A [1983], pp. 4-5).

4. Literature on Hicks' line is mainly centred on his Nobel lecture (1973) and related works (cf. in particular Hicks, 1977), where he insists on the continuity of his concern with 'the mainspring of economic growth', i.e., innovation. Although the mainstream of post-war economics assumes that such mainspring is speculation, Hicks gives the bases of his standpoint for granted. Such bases are the theme of the present article.

5. And Walras, albeit for mere didactical reasons ascribable to his Paretian pedigree.

6. As for his concern with Knight's distinction and terminology see §8. In fact, Hicks often called 'uncertainty' what economists, following Knight, are accustomed to calling 'risk', and vice versa: his 'Risk' was non-measurable risk, 'uncertainty' measurable risk (cf. e.g. 1973B [1977], pp. 137, 147; 1974B, pp. 37f). On the broader issue of Hicks' concern with risk and uncertainty see Hey (1994).

7. If all risks were actually measurable, holding money would be unnecessary, as any sum exceeding planned current expenditure (and insurance) would be lent until the day comes of the transaction scheduled to be financed with that sum. 
8. 'Gleichgewicht und Konjunktur' was published in 1933 and made available to English readers ('Equilibrium and the Cycle') only in 1980, thanks to R. Clower.

9. Whereas a stationary equilibrium is an equilibrium over a period of time, a flow-equilibrium, an equilibrium of an income account, a temporary equilibrium is a balance-sheet equilibrium, a stock-equilibrium, an equilibrium at a point in time.

10. 'If I am right, the whole problem of applying monetary theory is largely one of deducing changes in anticipations [learning] from the changes in objective data which call them forth' (1935A, p. 13). In my view, this sentence is Hicks' line in a nutshell.

11. The extension of the Wicksellian process to the dark side of the quantities was a major concern for both Keynes (1930) and Hayek (1931). On the wealth-effects of non-equilibrium transactions in Hicks' works of the 1930s, see Donzelli (2010, pp. 25ff).

12. 'The costs of transforming assets from one form to another' (1935A, p. 6). In the Theory of Wages they were called 'costs of change' (1932, p. 59), 'cost of changing' (ib.), 'costs of movement' (ib., pp. 60, 61, 62). 'This is of exactly the same character as the cost of transfer which acts as a certain impediment to change in all parts of the economic system; it doubtless comprises subjective elements as well as elements directly priced' (1935A, p. 6). Along these general notions, transaction costs ought rather be called 'transition costs' (I owe this point to an anonymous referee). That the emergence of the concept is to be dated (at least) back to the Theory of Wages is an aspect neglected by Klaes (2000), who stops at the Simplification.

13. In Hicks' oeuvre 'An important unifying theme was the attention to economic rationality 'in time' and his acknowledgement that apparent rigidities and frictions might exert a positive role as a buffer against excessive fluctuations in real and nominal magnitudes. This emphasis on the virtue of imperfection significantly distances him from both the Keynesian and monetarist approaches' (Scazzieri, Sen and Zamagni, 2008, p. i).

14. Lindahl is in London looking for someone to translate his works (Lindahl, 1939): he picks out Ursula Webb, scholar of public finance and future Mrs Hicks. 
15. Accounting excess supply as future supply, effective demand and current supply can be kept identical.

16. It is 'a clearer and sharper statement of my new view than anything ... The later work ['Methods of dynamic economics', rephrased twice (1965, pp. 1-127; 1985)] did add some useful detail, but in adding the detail the main points were obscured' (1982, p. 218).

17. 'I call Economic Statics those parts of economic theory where we do not trouble about dating; Economic Dynamics those parts where every quantity must be dated' (1939 [1946], p. 115). A good definition of a theory will refer to its object, not to its means.

18. In the terms of the Simplification, this theory is for 'deducing changes in anticipations [and plans] from the changes in objective data which call them forth' (1935A, p. 13). Since mistakes are now relevant in an ex-ante perspective only, plunged into non-measurable risk, the outcomes of such a theory can never be perfectly unambiguous as those vaunted by optimum theories.

19. An anticipation is a sunk cost in an ex-ante perspective, a 'crushing cost' (1970, p. 276) or, maybe better, a sinking cost.

20. 'The essential difference, when we pass to Fixprice theory, is that the position in which the firm finds itself at a point of time (at significant points of time) does not have to be [as in Flexprice theory] a position that is chosen ... it is by the absence of stock equilibrium that disequilibrium itself is carried forward. And it is the carrying forward of disequilibrium that is the interesting thing' $(1965$, p. 86).

21. 'Stocks may be allowed to pile up, until they become intolerable. But it is not the stocks themselves that become intolerable ... it is the financial effect of accumulating them that is the crux. More and more of the seller's capital becomes locked up in the unsold stocks, so his financial reserves continually fall. Even if he borrows to finance his holdings, his liquidity deteriorates' (1979B, p. 92).

22. Whereas optimality is a property of final positions, 'Flexibility is a property of initial positions. It refers to the 
cost, or possibility, of moving to various second period positions' (Jones and Ostroy, 1984, p. 16). Amendola (1991) gives a synthetic account of Hicks' line in monetary theory, and Hicks' notion of 'liquidity as flexibility' is explained and extended in a direction which calls into question the complementarity of his monetary theory and his neo-Austrian capital theory.

23. 'Even to this day, accountants are Fundists. It is not true, accountants will insist, that the plant and machinery of a firm are capital [the materialist approach]; they are not capital, they are assets. Capital, to the accountant, appears on the liabilities side of the balance sheet; plant and machinery appear on the assets side. Capital, accordingly, is a Fund that is embodied in the assets' (1974A [1977], p. 154).

24. 'If new projects are started, without savings (or the release of reserves) to match them, capital is just transmuted from one form to another - into the capital that is embodied in the early stages of the new processes from that which was embodied in the late stages of the old. It is possible, though not inevitable, that in the new form it will in the end be more useful; but this does not show up during the period of construction. At this stage there is bound to be a strain' (Hicks, 1990, p. 535).

25. 'Every business man must be risk-averse if he is planning to go on with his business. Even the gambler must be risk-averse if he plans to go on with his game. If he has ceased to be risk-averse he has just gone crazy. Risk-aversion is a consequence of rational behaviour' (1989, p. 142).

26. As 'the small saver who is dependent upon income from his investments' $(1977$, p. 172), the operator who 'has liabilities as well as assets or ... is carrying on a productive business which itself creates calls upon him' (1982, p. 254, 1989, p. 141). 